
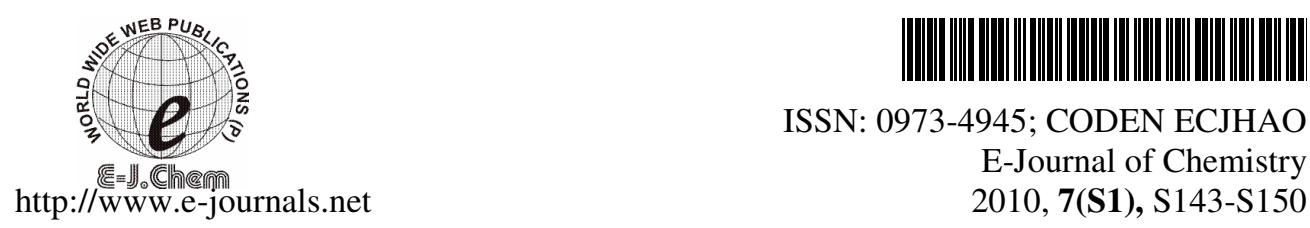

ISSN: 0973-4945; CODEN ECJHAO

E-Journal of Chemistry

2010, 7(S1), S143-S150

\title{
One Pot Synthetic Method of New Keto Diphenyl Selenide Compounds
}

\author{
YOUCEF MECHEHOUD ${ }^{\S *}$, F.BENAYACHE $^{\S}$, \\ S.BENAYACHE ${ }^{\S}$ and P.MOSSET \\ ${ }^{\S}$ Labo.VAREN, Département de Chimie, Faculté \\ Des Sciences Exactes, Université Mentouri, Constantine, Algérie \\ ENSChimie de Rennes,CNRS,UMR 6226, Avenue Gal Leclerc \\ CS 50837, 35708 Rennes Cedex 7, France \\ mechehoud_y@yahoo.fr
}

Received 28 February 2010; Accepted 1 May 2010

\begin{abstract}
A series of hitherto unreported mono- and di-keto diphenyl selenides have been efficiently synthesized in high yields by treatment of diphenyl selenide (1) with appropriately substituted acyl chloride using anhydrous aluminum chloride as catalyst and methylene chloride as solvent. The structures of the synthesized compounds have been confirmed by elemental and spectral analysis.
\end{abstract}

Keywords: Keto diphenyl selenides, Diphenyl selenides, Aluminum chloride, Acychloride.

\section{Introduction}

During the last few years, organoselenium chemistry ${ }^{1-8}$ has been the subject of constant scientific interest and organoselenium compounds have been used intensively as important reagents and intermediates in organic synthesis ${ }^{9-16}$.

The organoselenium compounds are of considerable interest in academia as well as anticancer $^{17,18}$, anti-oxydant ${ }^{19-25}$, anti-inflammatory, antiallergic agents ${ }^{26-29}$ and in industry because of their wide involvement as key intermediates for the synthesis of pharmaceuticals ${ }^{30-34}$, perfumes $^{35}$, fine chemicals and polymers ${ }^{36-38}$.

Furthermore, organoselenium compounds are no longer systematically classified as toxic and thus, much effort has been devoted toward synthesis of these compounds in recent times.

In the present study, we describe the synthesis of a series of hitherto unreported monoand diketo diphenyl selenides by a simple and efficient method, consisting essentially in the direct acylation of diphenyl selenide (1) mediated by anhydrous aluminum chloride as catalyst and methylene chloride as solvent under moderate conditions. 


\section{Experimental}

Diphenyl selenide (1) is malodorous and potentially toxic compound. All reactions and handling should be carried out in a well-ventilated hood.

Aluminum chloride is purchased from Acros and used as received. Solvents were used after purifying them by the established procedures. Progress of the reaction and purity of the compounds were monitored by thin layer chromatography (TLC) using ether-petrol $60^{\circ}$ and acetone $(4: 1$ by volume) as eluting system on silicagel (60-120 mesh) and U.V apparatus as visualizing agent. Evaporation of solvents was performed at reduced pressure, using a Buchi rotary evaporator.

\section{General}

Melting points were measured using a fine control Electro thermal capillary apparatus and uncorrected. ${ }^{1} \mathrm{H}(400.13 \mathrm{MHz})$ and ${ }^{13} \mathrm{C}$ NMR $(100.61 \mathrm{MHz})$ spectra were recorded on Brucker F.T. ARX 400 spectrometer in $\mathrm{CDCl}_{3}$ using TMS as internal standard. The IR spectra were recorded on Nicolet205 F.T. spectrometer as $\mathrm{KBr}$ pellets for solid. HRMS (high-resolution mass spectrometry) experiments were performed on a varian MAT 311 instrument. Elemental analyses were performed by the Central analysis of ENSC Rennes, France. HRMS (highresolution mass spectrometry) experiments were performed on a varian MAT 311 instrument by CRMPO (centre régional de mesures physiques de l'Ouest), Rennes, France as well as elemental analyses.

\section{General procedure for preparation of $\mathbf{3 a - i}$}

Synthesis of diphenyl selenium (1) was prepared according to a known method ${ }^{39}$. Acyl chloride derivatives, $\mathrm{RCOCl}$, (2.4 eq, $2.4 \mathrm{mmol}$.) and anhydrous aluminium chloride (3.0 eq., $3.0 \mathrm{mmol}$.) were taken in dry methylene chloride $(4 \mathrm{~mL})$. The reaction mixture was cooled at $0-5{ }^{\circ} \mathrm{C}$ and protected from atmosphere moisture. It was stirred continuously from $15 \mathrm{~min}$.

A solution of diphenyl selenide (1) $(1$ eq., $1 \mathrm{mmol})$ in methylene chloride $(0.5 \mathrm{~mL})$ was added drop wise over a period of $5 \mathrm{~min}$. to the above reaction mixture. The reaction mixture was allowed to reach room temperature gradually and then stirred at this temperature overnight.

The solution was then washed with ice water- $\mathrm{HCl}$ and extracted with methylene chloride. The organic layer was separated, dried $\left(\mathrm{Na}_{2} \mathrm{SO}_{4}\right)$. Removal of solvent afforded the crude product. The crude product thus obtained was recrystallized from $\mathrm{CH}_{3} \mathrm{OH}$ or chromatographed by column to furnish the diketone. The data obtained are summarized in Table 1.

Table 1. Acylation of diphenylselenide with $\mathrm{RCOCl}$

\begin{tabular}{cccccc}
\hline Compds & $\mathrm{R}$ & Molecular Formula & $\mathrm{FW}$ & \% yield & m.p ${ }^{\circ} \mathrm{C}$ \\
\hline $\mathbf{2 a}$ & $\mathrm{CH}_{3}$ & $\mathrm{C}_{14} \mathrm{H}_{12} \mathrm{OSe}$ & 275.204 & 52 & $65-66$ \\
$\mathbf{2 b}$ & $\mathrm{C}_{6} \mathrm{H}_{5}$ & $\mathrm{C}_{19} \mathrm{H}_{14} \mathrm{OSe}$ & 337.274 & 92 & $81-82$ \\
$\mathbf{2 c}$ & $\left(\mathrm{CH}_{3}\right)_{2} \mathrm{~N}$ & $\mathrm{C}_{15} \mathrm{H}_{15} \mathrm{NOSe}$ & 304.246 & 53 & 47 \\
$\mathbf{3 a}$ & $\mathrm{CH}_{3}$ & $\mathrm{C}_{16} \mathrm{H}_{14} \mathrm{O}_{2} \mathrm{Se}$ & 317.241 & 88 & $77-78$ \\
$\mathbf{3 b}$ & $\mathrm{C}_{6} \mathrm{H}_{5}$ & $\mathrm{C}_{26} \mathrm{H}_{18} \mathrm{O}_{2} \mathrm{Se}$ & 441.380 & 90 & 122 \\
$\mathbf{3 c}$ & $\left(\mathrm{CH}_{3}\right)_{2} \mathrm{~N}$ & $\mathrm{C}_{18} \mathrm{H}_{20} \mathrm{~N}_{2} \mathrm{O}_{2} \mathrm{Se}$ & 375.324 & 78 & 126 \\
$\mathbf{3 d}$ & $\mathrm{CH}_{3} \mathrm{CH}_{2}$ & $\mathrm{C}_{18} \mathrm{H}_{18} \mathrm{O}_{2} \mathrm{Se}$ & 345.294 & 94 & 134 \\
$\mathbf{3 e}$ & $\mathrm{CH}_{3}\left(\mathrm{CH}_{2}\right)_{2}$ & $\mathrm{C}_{20} \mathrm{H}_{22} \mathrm{O}_{2} \mathrm{Se}$ & 373.347 & 95 & 88 \\
$\mathbf{3 f}$ & $\mathrm{ClCH}_{2}$ & $\mathrm{C}_{16} \mathrm{H}_{12} \mathrm{Cl}_{2} \mathrm{O}_{2} \mathrm{Se}$ & 386.131 & 85 & 129 \\
$\mathbf{3 g}$ & $\mathrm{ClCH}_{2} \mathrm{CH}_{2}$ & $\mathrm{C}_{18} \mathrm{H}_{16} \mathrm{Cl}_{2} \mathrm{O}_{2} \mathrm{Se}$ & 414.184 & 93 & 86 \\
3h & $\left(\mathrm{CH}_{3} \mathrm{CH}_{2}\right)_{2} \mathrm{~N}$ & $\mathrm{C}_{22} \mathrm{H}_{28} \mathrm{~N}_{2} \mathrm{O}_{2} \mathrm{Se}$ & 431.430 & 75 & 135 \\
\hline
\end{tabular}




\section{Preparation of compounds $\mathbf{2 a - c}$}

Prepared from substituted acylchloride, $\mathrm{RCOCl}$ (1.2 eq., $1.2 \mathrm{mmol}$.), aluminum chloride (1.4 eq., $1.4 \mathrm{mmol}$.) and diphenylselenide (1.0 eq., $1.0 \mathrm{mmol}$.) according to above procedure.

\section{Selected physical and spectral data of the compounds}

\section{Diphenyl selenide (1)}

IR (neat, KBr): 3070, 3057, 3016, 2998, 1943 and 1877 and 1802 (small, harmonics of Ph), $1576,1476,1437,1065,1020,999,733,689,668,479,455 \mathrm{~cm}^{-1}$.

\section{(4-Acetylphenyl) phenyl selenide (2a)}

IR $\left(\mathrm{KBr}, \mathrm{cm}^{-1}\right)$ : 3371 (small, higher harmonic of $\mathrm{CO}$ ) , 3059, 3026, 2942, $1701(\mathrm{C}=\mathrm{O}), 1580$, 1396, 1391, 1216, 1207, 1190, 1184, 1062, 994, 822, 816, 774, 668, $561 \mathrm{~cm}^{-1} ;{ }^{1} \mathrm{H}$ NMR (400 $\mathrm{MHz}, \mathrm{CDCl}_{3}$ ): 7.79 (pseudo dt, $2 \mathrm{H}, J=8.7,2.0 \mathrm{~Hz}, \mathrm{H}_{\text {ortho }}$ to $\mathrm{CO}$ ), $7.62-7.56(\mathrm{~m}, 2 \mathrm{H}), 7.40$ $7.33(\mathrm{~m}, 5 \mathrm{H}), 2.55\left(\mathrm{~s}, 3 \mathrm{H}, \mathrm{CH}_{3}\right) ;{ }^{13} \mathrm{C} \mathrm{NMR}\left(100 \mathrm{MHz}, \mathrm{CDCl}_{3}\right): 197.37$ (CO), 140.32 (Cipso to $\mathrm{CO}), 135.13$ (Cipso to Se and para to $\mathrm{CO}), 135.12(2 \mathrm{CH}), 130.26(2 \mathrm{CH}), 129.73(2 \mathrm{CH})$, $128.91(2 \mathrm{CH}), 128.63\left(\mathrm{CH}_{\text {para }}\right), 128.42$ (Cipso to $\mathrm{Se}$ of $\left.\mathrm{Ph}\right), 26.49\left(\mathrm{CH}_{3}\right)$. HRMS: calcd for $\mathrm{C}_{14} \mathrm{H}_{12} \mathrm{OSe}$ : 276.1241; found: 276.1232. Anal. calcd. for $\mathrm{C}_{14} \mathrm{H}_{12} \mathrm{OSe}$ (275.204): $\mathrm{C} 61.10, \mathrm{H}$ 4.39, found: C 61.19, H 4.47\%. $\mathrm{R}_{\mathrm{f}}=0.62$ with acetone / E.P: 3 / 7 .

\section{(4-Benzoylphenyl)phenyl selenium (2b)}

IR $\left(\mathrm{KBr}, \mathrm{cm}^{-1}\right)$ : 3364 (small, higher harmonic of CO), 2931 (aromatic CH stretching), 1645 (CO stretching), ${ }^{1} \mathrm{H}$ NMR $\left(400 \mathrm{MHz}, \mathrm{CDCl}_{3}\right): 7.79-7.75(\mathrm{~m}, 2 \mathrm{H}), 7.66$ (pseudo dt, $2 \mathrm{H}, J=$ 8.6, $1.9 \mathrm{~Hz}, \mathrm{H}_{\text {ortho }}$ to $\left.\mathrm{CO}\right), 7.64-7.60(\mathrm{~m}, 2 \mathrm{H}), 7.58\left(\mathrm{ddt}, 1 \mathrm{H}, J=8.1,6.8,1.4 \mathrm{~Hz}, \mathrm{H}_{\text {para }}\right.$ of $\mathrm{Ph}$ ), $7.47\left(\mathrm{tm}, 2 \mathrm{H}, J=7.6 \mathrm{~Hz}, \mathrm{H}_{\text {meta }}\right.$ of $\mathrm{Ph}$ ), 7.40 (pseudo dt, $2 \mathrm{H}, J=8.6,1.9 \mathrm{~Hz}, \mathrm{H}_{\text {ortho }}$ to $\mathrm{Se}$ ), 7.39-7.36 (m, 2H, $\mathrm{H}_{\text {ortho }}$ of $\left.\mathrm{Ph}\right) ;{ }^{13} \mathrm{C}$ NMR (100 MHz, $\left.\mathrm{CDCl}_{3}\right): 195.99$ (CO), 139.50 (Cipso to $\mathrm{CO}$ ), 137.52 (Cipso to $\mathrm{CO}$ ), 135.49 (Cipso of $\mathrm{C}_{6} \mathrm{H}_{4}$ to $\mathrm{Se}$ ), $135.11(2 \mathrm{CH}$ ), 132.38 $\left(\mathrm{CH}_{\text {para }}\right), 130.77(2 \underline{\mathrm{CH}}), 130.09(2 \underline{\mathrm{CH}}), 129.91(2 \underline{\mathrm{CH}}), 129.73(2 \mathrm{CH}), 128.61\left(\mathrm{CH}_{\text {para }}\right)$, 128.50 (Cipso of Ph to Se), 128.29 (2 $\mathrm{CH}$ ). HRMS: calcd for $\mathrm{C}_{19} \mathrm{H}_{14} \mathrm{O}^{80} \mathrm{Se}: 338.1941$; found: 338.1932. Anal. calcd. for $\mathrm{C}_{19} \mathrm{H}_{14} \mathrm{OSe}$ (337.274): C 67.66, H 4.18: found: $\mathrm{C} 67.53, \mathrm{H} 4.27 \%$. $\mathrm{R}_{\mathrm{f}}=0.36$ with ACOEt / E.P* : $20 / 80$ ("E.P= éther de pétrole)

\section{4-Phenylseleno- $N, N$-dimethyl benzamide (2c)}

IR (neat, KBr) : 3054, 2928, 1634 (C=O of amide), 1395, 1267, 1086, 1014, 834, 741, $692 \mathrm{~cm}^{-1} ;{ }^{1} \mathrm{H}$ NMR (400 MHz, $\left.\mathrm{CDCl}_{3}\right)$ : 7.54-7.49 (m, 2H, H aromatic), $7.42(\mathrm{dt}, 2 \mathrm{H}, J=8.4,1.9 \mathrm{~Hz}, \mathrm{H}$ aromatic), 7.34-7.27 (m, 5H, H aromatic), 3.09 (broad s, 3H, N-CH $\mathrm{CH}_{3}$ ), 2.98 (broad s, 3H, N-CH 3 ); ${ }^{13} \mathrm{C}$ NMR (100 MHz, $\left.\mathrm{CDCl}_{3}\right): 171.06$ (CO), 134.78 (Cipso), 133.98 (Cipso), 133.94 (2 CH aromatic), 131.71(2 $\mathrm{CH}$ aromatic), 129.79 (Cipso), 129.52 (2 $\mathrm{CH}$ aromatic), 127.98 (2 $\mathrm{CH}$ aromatic), $127.95\left(\mathrm{CH}_{\text {para }}\right.$ of $\left.\mathrm{SePh}\right), 39.60$ (broad, N-CH $)$, 35.39 (broad, $\left.\mathrm{N}-\mathrm{CH}_{3}\right)$. HRMS: calcd for $\mathrm{C}_{15} \mathrm{H}_{15} \mathrm{NO}^{80} \mathrm{Se}$ : 305.1661 ; found: 305.1670 . Anal. calcd. for $\mathrm{C}_{15} \mathrm{H}_{15} \mathrm{NOSe}$ (304.246): C 59.22, $\mathrm{H}$ 4.97, N 4.60 found: C 59.25, H 4. 89, N 4.52\%. Orange oil; $\mathrm{R}_{\mathrm{f}}=0.23$ with $2 \% \mathrm{MeOH}-\mathrm{CH}_{2} \mathrm{Cl}_{2}$.

\section{4, 4'-Diacetyldiphenylselenide (3a)}

IR $\left(\mathrm{KBr}, \mathrm{cm}^{-1}\right)$ : 3375 (small, higher harmonic of CO), 2923 (aromatic CH stretching), 1650 (CO strerching); ${ }^{1} \mathrm{H}$ NMR (400 MHz, $\mathrm{CDCl}_{3}$ ) : 7.87 (pseudo dt, $4 \mathrm{H}, J=8.6,2.0 \mathrm{~Hz}, \mathrm{H}_{\text {ortho }}$ to $\mathrm{CO}$ ), 7.53 (pseudo dt, $4 \mathrm{H}, J=8.6,2.0 \mathrm{~Hz}, \mathrm{H}_{\text {ortho }}$ to $\left.\mathrm{Se}\right), 2.59\left(\mathrm{~s}, 6 \mathrm{H}, \mathrm{CH}_{3}\right) ;{ }^{13} \mathrm{C} \mathrm{NMR}(100 \mathrm{MHz}$, $\mathrm{CDCl}_{3}$ ) : 197.33 (CO), 137.18 (Cipso to $\mathrm{CO}$ ), 136.18 (Cipso to $\mathrm{Se}$ ), $132.68\left(\mathrm{CH}_{\text {ortho }}\right.$ to $\mathrm{CO}$ ), 129.21 $\left(\mathrm{CH}_{\text {ortho }}\right.$ to Se), $26.59\left(\mathrm{CH}_{3}\right)$. HRMS: calcd for $\mathrm{C}_{16} \mathrm{H}_{14} \mathrm{O}_{2}{ }^{80} \mathrm{Se}: 318.1611$; found: 318.1620 . Anal. calcd. for $\mathrm{C}_{16} \mathrm{H}_{14} \mathrm{O}_{2} \mathrm{Se}$ (317.241): C 60.57, $\mathrm{H}$ 4.45: found: $\mathrm{C} 60.49, \mathrm{H} 4.54 \%$. $\mathrm{R}_{\mathrm{f}}=0.42$ with acetone / E.P: 3/7. 


\section{4, 4-Di-benzoyldiphenylselenide (3b)}

IR $\left(\mathrm{KBr}, \mathrm{cm}^{-1}\right)$ : 3382 (small, higher harmonic of CO), 2941 (aromatic CH stretching), 1672 (CO stretching), ${ }^{1} \mathrm{H}$ NMR (400 MHz, $\left.\mathrm{CDCl}_{3}\right)$ : 7.78 - $7.75(\mathrm{~m}, 2 \mathrm{H}), 7.64$ (pseudo dt, $2 \mathrm{H}, J=$ 8.6, $1.9 \mathrm{~Hz}, \mathrm{H}_{\mathrm{O}}$ rtho to $\mathrm{CO}$ ), $7.63-7.60(\mathrm{~m}, 2 \mathrm{H}), 7.58$ (ddt, $1 \mathrm{H}, J=8.1,6.8,1.4 \mathrm{~Hz}, \mathrm{H}_{\text {para }}$ of $\mathrm{Ph}$ ), 7.40 (pseudo dt, $2 \mathrm{H}, J=8.6,1.9 \mathrm{~Hz}, \mathrm{H}_{\text {ortho }}$ to $\mathrm{Se}$ ); ${ }^{13} \mathrm{C} \mathrm{NMR}\left(100 \mathrm{MHz}, \mathrm{CDCl}_{3}\right): 195.96$ (CO), 139.55 (Cipso to CO), 137.49 (Cipso to CO), 135.51 (Cipso of $\mathrm{C}_{6} \mathrm{H}_{4}$ to $\mathrm{Se}$ ), 132.38 $\left(\underline{\mathrm{C}}_{\text {para }}\right), 130.74(2 \underline{\mathrm{CH}}), 130.11(2 \underline{\mathrm{CH}}), 129.91(2 \underline{\mathrm{CH}}), 128.29(2 \underline{\mathrm{CH}}) . \mathrm{HRMS}$ : calcd for $\mathrm{C}_{26} \mathrm{H}_{18} \mathrm{O}_{2}{ }^{80} \mathrm{Se}: 442.3001$; found: 442.291. Anal. calcd. for $\mathrm{C}_{26} \mathrm{H}_{18} \mathrm{O}_{2} \mathrm{Se}$ (441.380): C 70.75, $\mathrm{H}$ 4.11 found: C 78.67, H 4.15\%. $\mathrm{R}_{\mathrm{f}}=0.26$ with ACOEt / E.P: 20 / 80.

\section{4, 4'-Selenobis (N, N-dimethylbenzamide) (3c)}

IR (neat, KBr): 2929, 1635 and 1625 (Fermi resonance of C=O), 1394, 1261, 1086, 1011, $918,840,758$ with a shoulder at $754,659,564,553 \mathrm{~cm}-1 ;{ }^{1} \mathrm{H}$ NMR $\left(400 \mathrm{MHz}, \mathrm{CDCl}_{3}\right)$ : 7.49 (dt, $4 \mathrm{H}, J=8.4,1.9 \mathrm{~Hz}, \mathrm{H}$ aromatic), 7.34 (dt, $4 \mathrm{H}, J=8.4,1.9 \mathrm{~Hz}, \mathrm{H}$ aromatic), 3.11 (broad s, 6H, N-CH $), 2.99$ (broad s, 6H, N-CH $) ;{ }^{13} \mathrm{C} \mathrm{NMR} \mathrm{(100} \mathrm{MHz,} \mathrm{CDCl}_{3}$ ) : 170.94 (CO), 135.45 (Cipso), 132.83 ( $\mathrm{CH}$ aromatic), 132.58 (Cipso), 128.12 (CH aromatic), 39.61 (broad, $\mathrm{N}-\mathrm{CH}_{3}$ ), 35.40 (broad, $\mathrm{N}-\mathrm{CH}_{3}$ ). HRMS: calcd for $\mathrm{C}_{18} \mathrm{H}_{20} \mathrm{~N}_{2} \mathrm{O}_{2}{ }^{80} \mathrm{Se}$ : 376.2441 ; found: 376.2432. Anal. calcd. for $\mathrm{C}_{18} \mathrm{H}_{20} \mathrm{~N}_{2} \mathrm{O}_{2} \mathrm{Se}$ (375.32): C 57.60, H 5.37 N7.46: found: C 57.62, $\mathrm{H} 5.41, \mathrm{~N} 7.32 \%$. Yellow crystals; $\mathrm{R}_{\mathrm{f}}=0.24$ with $5 \% \mathrm{MeOH}-\mathrm{CH} 2 \mathrm{Cl} 2$.

\section{4,4'-Dipropanoylphenylselenide $\mathbf{( 3 d})$}

IR $\left(\mathrm{KBr}, \mathrm{cm}^{-1}\right)$ : 3355 (small, higher harmonic of CO), 2912 (aromatic CH stretching), 1644 (CO stretching), ${ }^{1} \mathrm{H}$ NMR (400 MHz, CDCl3) : 7.87 (pseudo dt, $4 \mathrm{H}, J=8.6,1.9 \mathrm{~Hz}, \mathrm{H}_{\text {ortho }}$ to $\mathrm{CO}$ ), 7.53 (pseudo dt, $4 \mathrm{H}, \mathrm{J}=8.6,2.0 \mathrm{~Hz}, \mathrm{H}_{\text {ortho }}$ to $\mathrm{Se}$ ), $2.98\left(\mathrm{q}, 4 \mathrm{H}, J=7.2 \mathrm{~Hz}, \mathrm{CH}_{2}\right), 1.22(\mathrm{t}, 6 \mathrm{H}, \quad J$ $\left.=7.2 \mathrm{~Hz}, \mathrm{CH}_{3}\right) ;{ }^{13} \mathrm{C}$ NMR $\left(100 \mathrm{MHz}, \mathrm{CDCl}_{3}\right): 200.03(\mathrm{CO}), 136.86$ (Cipso to $\left.\mathrm{CO}\right), 135.95$ (Cipso to $\mathrm{Se}), 132.67\left(\mathrm{CH}_{\text {ortho }}\right.$ to $\left.\mathrm{CO}\right), 128.87\left(\mathrm{CH}_{\text {ortho }}\right.$ to $\left.\mathrm{Se}\right), 31.78\left(\mathrm{CH}_{2}\right), 8.17\left(\mathrm{CH}_{3}\right) . \mathrm{HRMS}$ : calcd for $\mathrm{C}_{18} \mathrm{H}_{18} \mathrm{O}_{2}{ }^{80} \mathrm{Se}: 366.2141$; found: 346.2125. Anal. calcd. for $\mathrm{C}_{18} \mathrm{H}_{18} \mathrm{O}_{2} \mathrm{Se}$ (345.294): $\mathrm{C}$ 62.61, H 5.25: found: C 62.53, H 5.27\%. $\mathrm{R}_{\mathrm{f}}=0.38$ with acetone / E.P: $3 / 7$.

\section{Di (4-butanoylphenyl)selenide (3e)}

IR $\left(\mathrm{KBr}, \mathrm{cm}^{-1}\right)$ : 3358 (small, higher harmonic of $\mathrm{CO}$ ), 2933 (aromatic $\mathrm{CH}$ stretching), 1683(CO stretching), ${ }^{1} \mathrm{H}$ NMR (400 MHz, $\mathrm{CDCl}_{3}$ ) : 7.87 (pseudo dt, $4 \mathrm{H}, J=8.6,2.0 \mathrm{~Hz}$, $\mathrm{H}_{\text {ortho }}$ to $\mathrm{CO}$ ), 7.53 (pseudo dt, $4 \mathrm{H}, \mathrm{J}=8.6,2.0 \mathrm{~Hz}, \mathrm{H}_{\text {ortho }}$ to $\mathrm{Se}$ ), 2.92 (dd, $4 \mathrm{H}, J=7.4,7.2$ $\mathrm{Hz}, \mathrm{CH}_{2}$ ), 1.77 (qdd, $4 \mathrm{H}, \mathrm{J}=7.4,7.4,7.2 \mathrm{~Hz}, \mathrm{CH}_{2} \mathrm{CH}_{3}$ ), 1.00 (t, $6 \mathrm{H}, \mathrm{J}=7.4 \mathrm{~Hz}, \mathrm{CH}_{3}$ ); ${ }^{13} \mathrm{C}$ NMR (100 MHz, $\mathrm{CDCl}_{3}$ ): 199.64 (CO), 136.87 (Cipso : to CO), 136.14 (Cipso : to Se), $132.66\left(\mathrm{CH}_{\text {ortho }}\right.$ to $\left.\mathrm{CO}\right), 128.94\left(\mathrm{CH}_{\text {ortho }}\right.$ to $\left.\mathrm{Se}\right), 40.48\left(\mathrm{CH}_{2} \mathrm{CO}\right), 17.71\left(\mathrm{CH}_{2} \mathrm{CH}_{3}\right), 13.87$ $\left(\mathrm{CH}_{3}\right)$. HRMS: calcd for $\mathrm{C}_{16} \mathrm{H}_{12} \mathrm{Cl}_{2} \mathrm{O}_{2}{ }^{80} \mathrm{Se}$ : 374.2671; found: 374.2665 . Anal. calcd. for $\mathrm{C}_{20} \mathrm{H}_{22} \mathrm{O}_{2} \mathrm{Se}$ (373.347): C 54.42, H 5.02: found: C 54.40, H 4.98\%. $\mathrm{R}_{\mathrm{f}}=0.62$ with acetone / E.P: $3 / 7 . \mathrm{R}_{\mathrm{f}}=0.34$ with acetone / E.P: $3 / 7$.

\section{4, 4'-Dichloroacétyldiphénylsélénide (3f)}

IR $\left(\mathrm{KBr}, \mathrm{cm}^{-1}\right)$ : 3382 (small, higher harmonic of CO), 3076, 3059, 3043, 3026, 2974, 2942, 2930, 1701 (C=O), 1580, 1396, 1391, 1216, 1207, 1190, 1184, 1062, 994, 822, 816, 774, $668,561 \mathrm{~cm}^{-1} ;{ }^{1} \mathrm{H}$ NMR (400 MHz, $\left.\mathrm{CDCl}_{3}\right): 7.88$ (dt, $4 \mathrm{H}, J=8.6,1.9 \mathrm{~Hz}, \mathrm{H}_{\text {ortho }}$ to $\mathrm{CO}$ ), 7.57 (dt, $4 \mathrm{H}, J=8.6,2.0 \mathrm{~Hz}, \mathrm{H}_{\text {ortho }}$ to $\left.\mathrm{Se}\right), 4.68\left(\mathrm{~s}, 4 \mathrm{H}, \mathrm{CH}_{2} \mathrm{Cl}\right) ;{ }^{13} \mathrm{C} \mathrm{NMR}(100 \mathrm{MHz}$, $\mathrm{CDCl}_{3}$ ) : 190.41 (CO), 138.24 (Cipso to Se), 133.28 (Cipso to $\mathrm{CO}$ ), $132.87\left(\mathrm{CH}_{\text {ortho }}\right.$ to $\mathrm{Se}$ ), 129.44 ( $\mathrm{CH}_{\text {ortho }}$ to $\left.\mathrm{CO}\right), 45.73\left(\mathrm{CH}_{2} \mathrm{Cl}\right)$.HRMS: calcd for $\mathrm{C}_{18} \mathrm{H}_{16} \mathrm{Cl}_{2} \mathrm{O}_{2}{ }^{80} \mathrm{Se}$ : 387.0511 ; found: 387.0504. Anal. calcd. for $\mathrm{C}_{16} \mathrm{H}_{12} \mathrm{C}_{12} \mathrm{O}_{2} \mathrm{Se}$ (386.131):C 49.76, H 3.13: found:C49.70, H 3.16 $\mathrm{R}_{\mathrm{f}}=0.42$ with acetone /E.P: $3 / 7$. 


\section{Di (4-(3-chloropropanoyl)phenyl)selenide (3g)}

IR $\left(\mathrm{KBr}, \mathrm{cm}^{-1}\right): 3379$ (small, higher harmonic of $\mathrm{CO}$ ), 3076, 3059, 1580 (CO stretching), ${ }^{1} \mathrm{H}$ NMR (400 MHz, $\mathrm{CDCl}_{3}$ ) : 7.87 (pseudo dt, $4 \mathrm{H}, J=8.6,2.0 \mathrm{~Hz}, \mathrm{H}_{\text {ortho }}$ to $\mathrm{CO}$ ), 7.55 (pseudo dt, $4 \mathrm{H}, J=8.6,2.0 \mathrm{~Hz}, \mathrm{H}_{\text {ortho }}$ to $\mathrm{Se}$ ), 3.92 (t, $\left.4 \mathrm{H}, J=6.8 \mathrm{~Hz}, \mathrm{CH}_{2} \mathrm{Cl}\right), 3.44$ (t, $4 \mathrm{H}, J=6.8 \mathrm{~Hz}$, $\mathrm{CH}_{2} \mathrm{CO}$ ); ${ }^{13} \mathrm{C}$ NMR (100 MHz, $\mathrm{CDCl}_{3}$ ) : 195.92 (CO), 137.71 (Cipso to $\mathrm{CO}$ ), 135.43 (Cipso to $\mathrm{Se}), 132.79\left(\mathrm{CH}_{\text {ortho }}\right.$ to $\left.\mathrm{CO}\right), 128.95\left(\mathrm{CH}_{\text {ortho }}\right.$ to $\left.\mathrm{Se}\right), 41.19\left(\mathrm{CH}_{2} \mathrm{CO}\right), 38.54\left(\mathrm{CH}_{2} \mathrm{Cl}\right)$. HRMS: calcd for $\mathrm{C}_{18} \mathrm{H}_{16} \mathrm{Cl}_{2} \mathrm{O}_{2}{ }^{80} \mathrm{Se}$ : 415.1041; found: 415.1026. Anal. calcd. for $\mathrm{C}_{18} \mathrm{H}_{16} \mathrm{Cl}_{2} \mathrm{O}_{2} \mathrm{Se}$ (414.184): C 52.19, H 3.89: found: C 52.27, H 3.97\%. $\mathrm{R}_{\mathrm{f}}=0.48$ with acetone / E.P: 3 / 7.

\section{4, 4'-Seleno bis ( $N$, $N$-diethylbenzamide) (3h)}

${ }^{1} \mathrm{H}$ NMR (400 MHz, $\left.\mathrm{CDCl}_{3}\right): 7.49(\mathrm{dt}, 4 \mathrm{H}, J=8.3,1.9 \mathrm{~Hz}, \mathrm{H}$ aromatic), $7.29(\mathrm{dt}, 4 \mathrm{H}, J=$ 8.3, $1.9 \mathrm{~Hz}, \mathrm{H}$ aromatic), 3.67-3.40 (broad, 2H, N-CH2), 3.37-3.10 (m, centered at 3.26 ppm, $2 \mathrm{H}, \mathrm{N}-\mathrm{CH}_{2}$ ), 1.35-1.00 (two m centered at 1.23 and $1.12 \mathrm{ppm}, 2 \times 3 \mathrm{H}, \mathrm{CH}_{3}$ ); ${ }^{13} \mathrm{C} \mathrm{NMR}$ $\left(100 \mathrm{MHz}, \mathrm{CDCl}_{3}\right): 170.59$ (CO), 136.43 (Cipso), 132.94 (CH aromatic), 132.02 (Cipso), $127.36\left(\mathrm{CH}\right.$ aromatic), 43.31 (broad, $\left.\mathrm{N}-\mathrm{CH}_{2}\right), 39.31$ (broad, $\mathrm{N}-\mathrm{CH}_{2}$ ), 14.26 (broad, $\mathrm{CH}_{3}$ ), 12.88 (broad, $\mathrm{CH}_{3}$ ). HRMS: calcd for $\mathrm{C}_{22} \mathrm{H}_{28} \mathrm{~N}_{2} \mathrm{O}_{2} \mathrm{Se}$ : 432.3501; found:432.3512. Anal. calcd. for $\mathrm{C}_{22} \mathrm{H}_{28} \mathrm{~N}_{2} \mathrm{O}_{2} \mathrm{Se}$ : 431.430: C 61.24, $\mathrm{H}$ 6.54, N 6.49: found: C 61.19, H 6.52, N 6.41 $\% . \mathrm{R}_{\mathrm{f}}=0.22$ with $5 \% \mathrm{MeOH}-\mathrm{CH}_{2} \mathrm{Cl}_{2}$

\section{Results and Discussion}

We first studied the reaction of acetyl chloride with diphenyl selenide (1) in the presence of anhydrous aluminum chloride as catalyst and different solvents (Scheme 1).

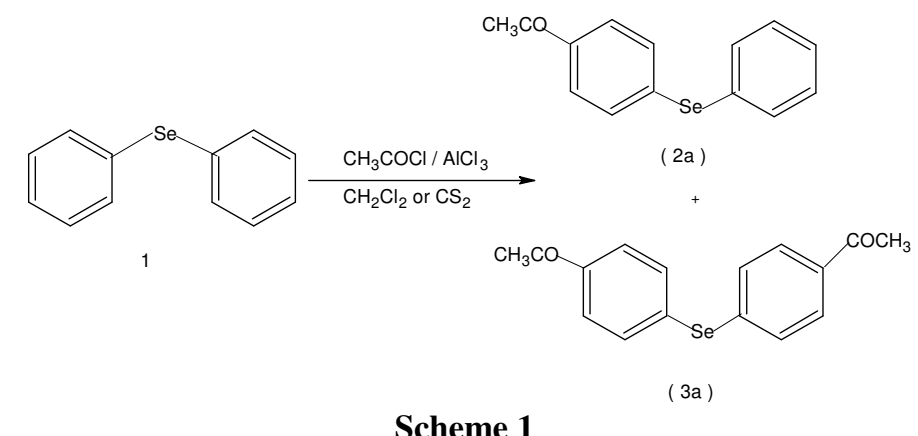

\section{Scheme 1}

By the initial mixing of substrate (1) and anhydrous aluminum chloride, followed by the addition of the acylation agent $\left(\mathrm{CH}_{3} \mathrm{COCl}\right)$, different solvents were tested for the purpose. No acylation product was detected in acetonitrile, chlorobenzene, toluene, nitrobenzene, 1, 2-dichloroethane used as solvents.

Low and moderate yields of mono and disubstituted products (2a) and (3a) were obtained in methylene chloride or carbon sulphide, respectively. However, in practice, by products formation in high proportions make difficult the isolation of (2a) and (3a) in a pure form.

It may be suggested that selenium atom, owing to its lone electron pairs, very highly forms a dative bond with aluminum chloride $\left(\mathrm{AlCl}_{3}\right)$, when the two compounds are mixed in the very first stage of the reaction. Degradation of the resulting complex into undesirable products is probably much favoured over acylation (Scheme 1).

To overcome this difficulty, the order of addition of reactants was inverted. Hence, acylchloride $\left(\mathrm{CH}_{3} \mathrm{COCl}\right)$ and anhydrous aluminum chloride $\left(\mathrm{AlCl}_{3}\right)$ were mixed and diphenyl selenide (1) was added drop by drop in a second stage. ( $c f$. experimental section). 
Dichloromethane was found to be a good solvent and was used in all experiments, hence avoiding the bad odour of carbon sulphide. High yield of 4-acethyldiphenylselenide (2a) and 4,4'-diacethyl diphenyl selenide (3a) were obtained in this way (Scheme 2). Although involving the same reactants and catalyst (Scheme 2) was more successful than Scheme 1, which supports the hypothesis of the formation of an unstable diphenyl selenide aluminum chloride complex in Scheme 1. Besides, unlike what was observed in Scheme 1, the resulting solution was clear and the reaction products easily isolated by column chromatography or recrystallisation. The proportions in which (2a) and (3a) were produced depended on the relative amount of acyl chloride introduced. As expected, the proportion of (3a) in the mixture increases with an increase of the equivalent number of (2a).<smiles>COc1ccc([Se]c2ccccc2)cc1</smiles>

( 2a )

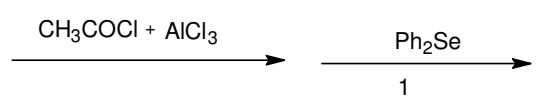<smiles>COc1ccc([Se]c2ccc(C(C)=O)cc2)cc1</smiles>

\section{Scheme 2}

( 3 a )

The acylation of (1) with substituted acyl chlorides ( $\mathrm{RCOCl}$ ) was studied in the same way as with $\mathrm{CH}_{3} \mathrm{COCl}$, according to Scheme 2. As shown in Scheme 3 and Table 1, acylation of (1) with $\mathrm{RCOCl}$ gave high yields of the para substituted isomers. As with acyl chloride, a mixture of the mono and di-substituted products was observed for three entries (2a-c) while only the disubstituted product was observed for the others entries (3d-i).

Complete conversion of (1) was observed and no trace of the ortho isomer was detected, indicating a total regioselectivity in all cases which however cannot be limited to monoacylation. Considering the ortho/para orientating mesomeric effect of selenium, the absence of the ortho isomers is rather unexpected but may be explained either (i) by the steric hindrance of the ortho position by the bulky Se-C6H5 group or (ii) by the repulsive force between two positive charges ( $-\mathrm{S}^{+}=$and $\mathrm{RCO}^{+}$) which favours substitution on the carbon that is most distant from selenium or (iii) by a combination of the two effects.<smiles>CC(=O)Oc1ccc([Se]c2ccccc2)cc1</smiles>

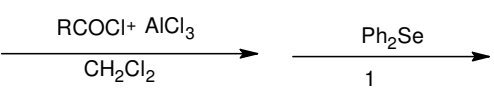

$(2 \mathrm{a}-\mathrm{c})$<smiles>CC(=O)Oc1ccc([Se]c2ccc(C(=O)O)cc2)cc1</smiles>

Scheme 3 


\section{Conclusion}

We successfully synthesized a series of hitherto unreported keto diphenyl selenides in high yields by adopting a simple and efficient procedure. These new substituted diphenyl selenide are very stable compounds which renders them beneficial for biological, pharmaceutical trials

\section{Acknowledgment}

We gratefully acknowledge Dr Jean-Claude Guillemin, director of the research team COS (Chimie Organique Supramoléculaire), ENSChimie de Rennes, CNRS, UMR 6226 (France) for providing necessary facilities during the tenure of this work and the MESRS (Ministère de l'enseignement supérieur et de la recherche scientifique of Algerian republic) for financial support.

\section{References}

1. Procter D J, J Chem Soc Perkin Trans., 2001, 1, 335.

2. Organoselenium Chemistry, Topics in Current Chemistry, Edited by $\mathrm{T}$ Wirth, Springer Verlag, Heidelberg, 2000.

3. Taniguchi N and Onami T, J Org Chem., 2004, 69, 915.

4. Gujadhur R K and Venkataraman D, Tetrahedron Lett., 2003, 44, 81-84.

5. Nishiyama Y, Tokunaga K and Sonoda N, Org Lett., 1999, 1, 1725-1727.

6. Beletskaya P I, Sigeev A S, Peregudov A S and Petrovskii P V, Tetrahedron Lett., 2003, 44, 7039.

7. Taniguchi N and Onami T, Synlett., 2003, 829-832.

8. Kosugi M, Ogata T, Terada M, Sano H and Migita T, Bull Chem Soc Jpn., 1985, 58, 3657

9. Zade Sanjio S, Panda Snigdha, Singh Harkesh B and Wolmershaeuser Gotthelf, Tetrahedron Lett., 2005, 46(4), 665-669.

10. Kang S I and Spears C P, J Pharm Sci., 1990, 79(1), 57-62

11. Beletskaya I P, Sigeev A S, Peregudov A S and Petrovskii P V, Russia $J$ Organometallic Chem., 2000, 605(1), 96-101

12 Gujadhur Rattan K and Venkataraman D, Amherst Tetrahedron Letters, 2003, 44(1), 81-84

13. Paulmier C, Selenium Reagents and Intermediates in Organic Synthesis, Pergamon: Oxford, 1985.

14. Patai S and Rappoport Z, Chemistry in Organoselenium and Tellurium Compounds, Eds., John Wiley \& Sons, New York, 1987.

15. Back T G, Organoselenium Chemistry: A practical Approach, Ed., Oxford University Press: Oxford, 1999.

16. Wirth T, Topics in Current Chemistry, Ed., Springer: Heidelberg, 2000.

17. Zhu Zongjian and Jiang Weiqin, Biomedical Research on Trace Elements, 2008, 19(4), 282-289.

18. Ip Clement, Lisk Donald J, Ganther Howard and Thompson Henry J, Anticancer Res., 1997, 17(5A), 3195-3199.

19. Andersson Carl Magnus, Hallberg Anders, Linden Margareta, Brattsand Ralph, Moldeus Peter and Cotgreave Ian, Free Radical Biology \& Med., 1994, 16(1), 17-28.

20. Renson M and Dereu N, Journal De Pharmacie De Belgique, 1990, 45(5), 322-330.

21. Engman L, Stern D, Pelcman M and Andersson C M, J Org Chem., 1994, 59(8), 1973-1979.

22 Anderson C M, Hallberg A and Hogberg T, Adv Drug Res., 1996, 28, 65-180.

23 Malmstrom J, Jonsson M and Cotgreave I A, Hammarsöm L, Sjödin M and Engman L, J Am Chem Soc., 2001, 123, 3434-3440. 
24 Mugesh G and Singh H B, Chem Soc Rev., 2000, 29, 347-357.

25 Mugesh G, du Mont W W and Sies H, Chem Rev., 2001, 101, 2125-2179.

26. Martinez Ramos Federico, Salgado Zamora Hector, Campos Aldrete Maria Elena, Melendez Camargo Estela, Marquez Flores Yazmin and Soriano Garcia Manuel, European J Med Chem., 2008, 43(7), 1432-1437.

27. Shamberger R J, Biochemistry of Selenium, Frieden E, Ed. Plenum Press, 1983, Ch.7.

28. Abdel Hafez Sh H, European J Med Chem., 2008, 43(9), 1971-1977.

29. Galet V, Bernier J L and Henichart J P, J Med Chem., 1994, 37, 2903-2911.

30. Kondo S, Japanese J Med Sci., Part 4: Pharmacol., 1935, 9, 29-58.

31. Woods J A, Hadfield J A, McGown A T and Fox B W, Bioorganic Med Chem., 1993, 1(5), 333-340.

32. (a) Agenas L B, Gunther W H, Kayman D L, Organic Selenium Compounds: Their Chemistry and Biology, John Wiley and Sons: London, 1973; (b) Baird C P, Rayner C M, J Chem Soc., Perkin Trans I, 1998, 1973-2003.

33. Parnham M J and Graf Erich, Progress in Drug Research, 1991, 36, 9-47.

34. $\mathrm{Hu}$ Chun, Zhang Pu, Li Huiyuan, Ji Zhizhong, Liu Baili, Huaxue Tongbao, 2002, 65(3), 162-166.

35. Bernardon J M and Diaz P, PCT Int Appl., 1999, 81.

36. Jen K Y, Lakshmikantham M V, Albeck M, Cava, M P, Huang W S and MacDiarmid A G, J Polym Sci Polym Lett Ed., 1983, 21(6), 441-444.

37. Hellberg J, Remonen T, Johansson M, Inganaes O, Theander M, Engman L and Eriksson P, Synthetic Metals, 1997, 84(1-3), 251-252.

38. Sandman D J, Michael Rubner and Samuelson L, J Chem Soc Chem Commun., 1982, 9, 1133-1134.

39. Henry M L, Org Synth Coll., 1943, 2, 238-240. 


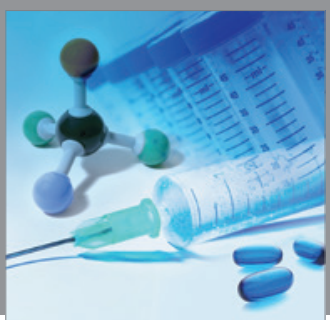

International Journal of

Medicinal Chemistry

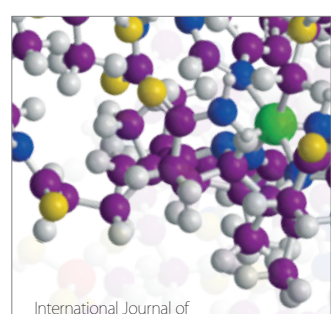

Carbohydrate Chemistry

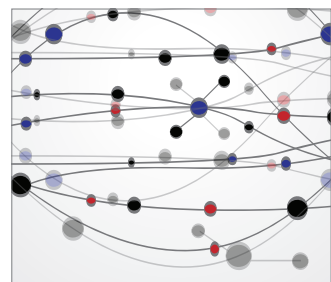

The Scientific World Journal
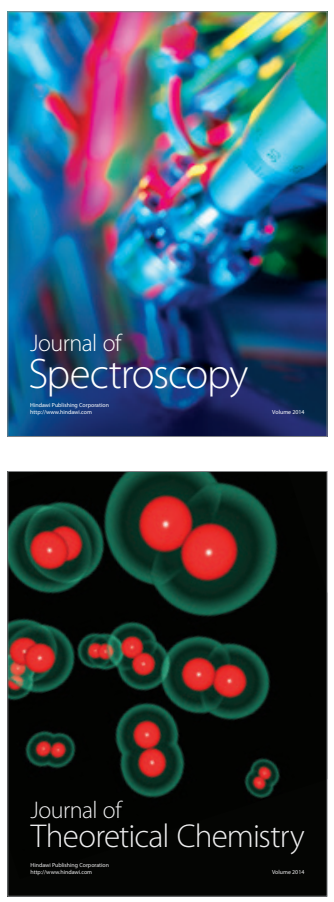
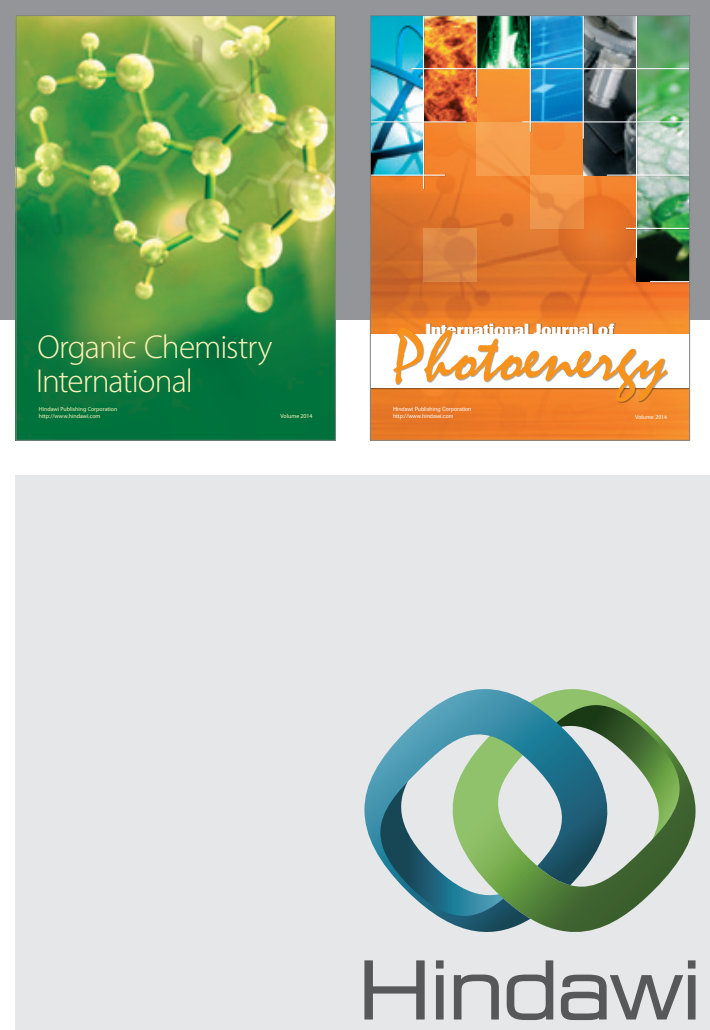

Submit your manuscripts at

http://www.hindawi.com
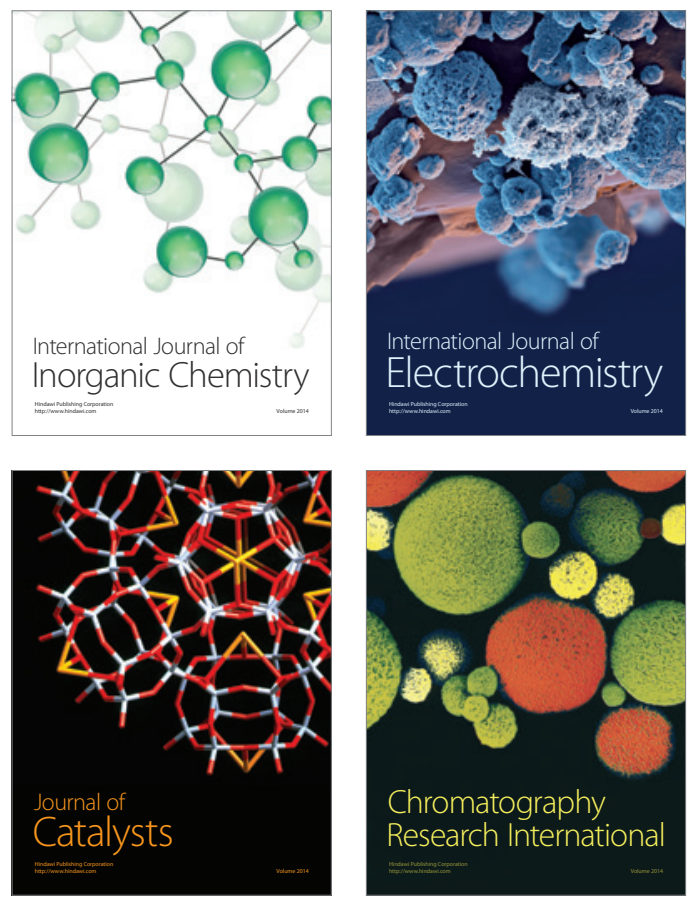
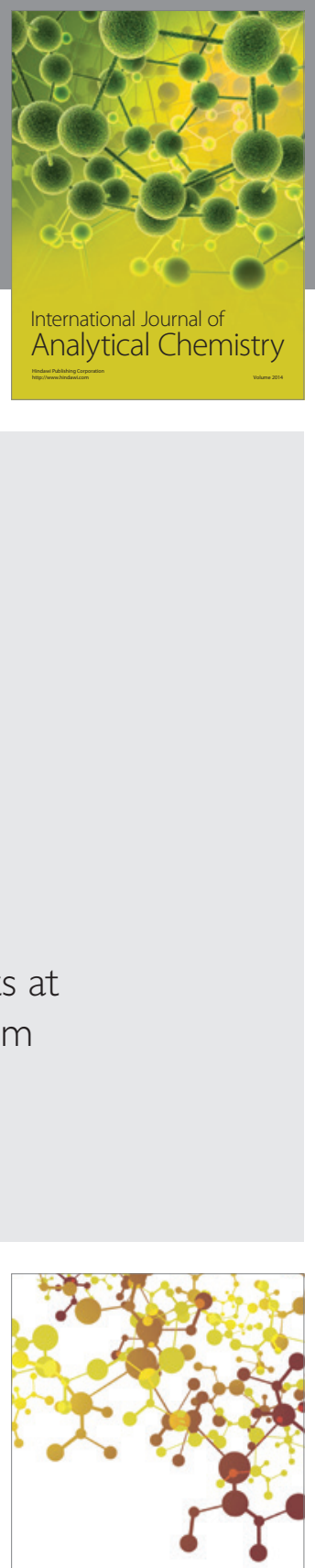

Journal of

Applied Chemistry
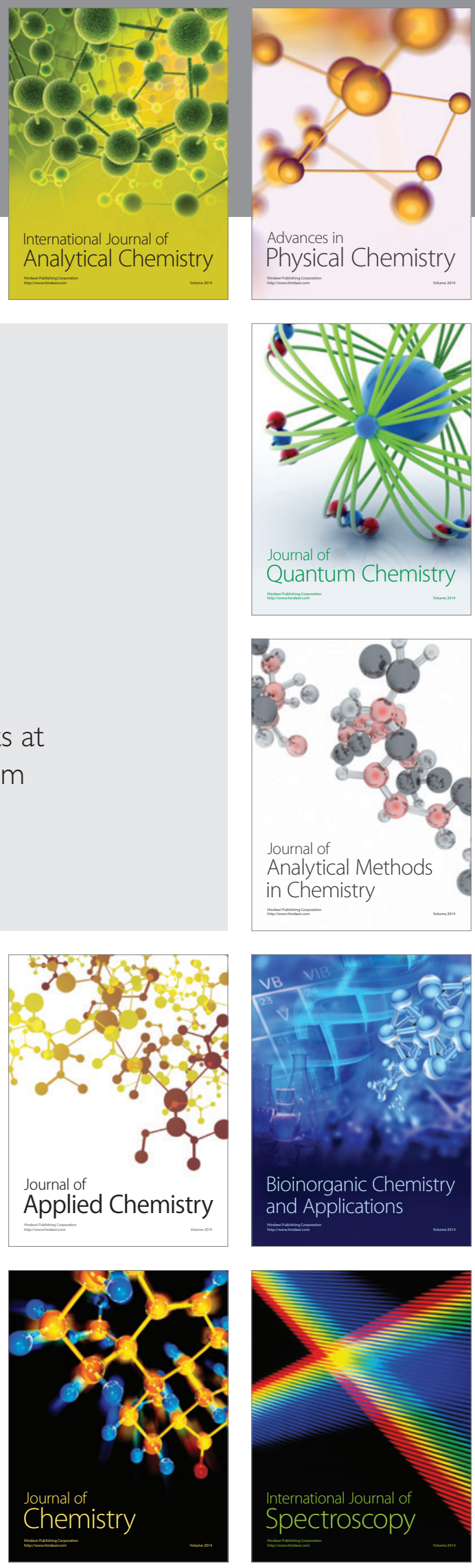